\title{
TRADER TYPE EFFECTS ON THE VOLATILITY-VOLUME RELATIONSHIP EVIDENCE FROM THE KOSPI 200 INDEX FUTURES MARKET
}

\author{
Aris Kartsaklas \\ Brunel University London, London, UK
}

\begin{abstract}
We investigate whether the trading activity generated by investors with different access to information and trading motives has positive or negative impact on index futures volatility. Surprises in non-member institutional, individual and foreign investors' trading volume are positively associated with volatility in most of the cases. For member institutional investors, unexpected trading volume is positively related to volatility. Long-run changes in the trading activity also affect volatility differently across trader types. Finally, allowing for time-to-maturity effects, surprises in open interest are associated with more volatility towards contract expiration, contrary to the negative effect we find during normal times.
\end{abstract}

Keywords: financial crisis, futures markets, institutional investors, range based volatility, trading volume

JEL Classification: G14, G15, G20

\section{INTRODUCTION}

The process of price discovery and information assimilation under different market settings has been a key element of market microstructure research (O’Hara, 1995). Theoretical market microstructure models associate movements in prices and trading volume with the arrival of new information, the expectations formed when new information arrives and the trading motives of investors. The arrival of new information is usually associated with more volatility in rational expectations and dispersion of beliefs models (Harris and Raviv, 1993; Shalen, 1993). ${ }^{1}$ The

Correspondence: Aris Kartsaklas, Department of Economis and Finance, Brunel University London, Kingston Lane, Uxbridge, Middlesex, UB8 3PH, UK. Email: aris.kartsaklas@brunel.ac.uk, tel: +44(0)1895267259, fax: +44 (0)1895269770.

${ }^{1}$ In the first set of models, investors can't easily differentiate whether it is the new private information or the 'noisy' liquidity demand they trade against and, thus, the increased volatility reflects the price movement necessary to induce uninformed traders to take the other side of the trade. In the dispersion of beliefs models, it is not always clear how information obtained by traders relates to the ultimate value of the firm and, hence, not immediately apparent how unbiased or how valuable the information is. The price variability-volume relationship arises, then, because the volume of trading is positively related to the extent to which traders disagree when they revise their reservation prices. 
theory, also, does not preclude a negative relation between volume and volatility when the marketplace has increased liquidity ( $\mathrm{Li}$ and $\mathrm{Wu}, 2006$ ), an increasing number of active investors (Tauchen and Pitts, 1983) and high consensus among investors when new information is released (Holthaussen and Verrechia, 1990; Hindy, 1994). ${ }^{2}$ Keim and Madhavan (1995) find considerable heterogeneity in investment style (active or passive) and choice of order type (market or limit) across institutions. For example, institutional traders who engage in herding or positive feedback trades can destabilize the market, while contrarian or value motivated trades are likely to reduce short run volatility (Delong et al., 1990b; Avramov et al., 2006). Moreover, individual investors' trades are affected by psycological biases that largely explain why retail investors trade so much, self-manage and under-diversify their stock portfolios (Barber and Odean, 2011).

Bessembinder and Seguin (1993) suggest that the volatility-volume relationship might depend on the type of trader, especially after finding that trades causing changes in open interest have a larger effect on volatility than trades that leave the open interest unchanged. Empirical evidence of trader-type effects on volatility is almost restricted to a small number of studies due to the lack of trader-type volume data (Daigler and Wiley, 1999; Avramov et al., 2006; Chen and Daigler, 2008). This study contributes new empirical evidence on the literature about trader type behavior and its impact on volatility. Daigler and Wiley (1999) find that using trader categories is a better way to describe the link between volatility and volume than total volume. Their empirical results for the futures market show that the general public drives the positive volatility-volume relationship whereas trading by clearing members and floor traders often exhibits an inverse relationship between volatility and volume. This study investigates whether the trading activity generated by investors with different access to information (members vs non-members ${ }^{3}$ ) and trading motives (institutions vs individuals) has a positive or negative effect upon index futures volatility. The effect of changes in open interest on futures volatility is also examined here. This will contribute additional evidence on the ability of the market to absorb trading volume shocks by the different types of traders. ${ }^{4}$ Another contribution of this paper is to assess whether the behaviour of traders changes close to the expiration date of the futures contract. A number of studies allow for different time-to-maturity patterns in futures price volatility and open interest depending on who trades and whether information asymmetry rises as the contact rolls to its expiration (Hong, 2000).

The case of Korea is particularly interesting as it has enjoyed increased economic performance $^{5}$ and capital inflows ${ }^{6}$ from 1996 to 2005. The Asian financial crisis in 1997 also brought changes in the Korean financial system such as abolishing foreign ownership ceiling in the stock market, allowing free movement of the profit on investment, and providing transparent financial reports. These developments together with the introduction of futures trading in the Korean Stock Exchange in 1996 raise interesting research questions about their impact on the volatility and trading activity of the spot and futures markets.

\footnotetext{
${ }^{2}$ On the empirical side, Karpoff (1987) cites eighteen separate studies that document a positive contemporaneous correlation between trading volume and price volatility in a variety of financial markets including equities, futures, currencies, and Treasury bills.

${ }^{3}$ Members of the Korean Stock Exchange have direct access to the trading system and have the right to trade and the responsibility of clearing the trade. This gives them an information advantage compared to non-members who can access the KSE system only indirectly by connecting to a member's trading pit.

${ }^{4}$ For example, a negative coefficient on open interest means that a trade which increases both volume during the day and open interest at the end of the day has a smaller effect on volatility than a trade that increases volume but decreases open interest or leaves it unchanged.

${ }^{5}$ From 1996 to 2005, the Korean GDP grew at an average pace of 5 percent (per year) reaching the maximum of 10.7 percent in 1999.

${ }^{6}$ The Korean futures market, which is an emerging market, shows an exponential growth in trading activity during the period of study. Specifically, the ratio of KOSPI200 futures to cash trading value increased from 0.32 in 1997 to 3.87 in 2005 (KSE Factbook 2003-05), i.e., more than 12 times over a period of 9 years.
} 
A unique dataset is available which consists of trading volume for eight different types of domestic investors, foreign investors and open interest who trade index futures in the Korean Stock Exchange (KSE). Trading volume is aggregated into four categories based on investor type (institutional, individual) and access to the trading system (member, non-member). Using open interest in conjunction with volume data should provide insights into the price effects of market activity generated by informed versus uninformed traders (information) or hedgers versus speculators (motives). ${ }^{7}$ The econometric technique used in this study (Schwert, 1990; Davidian and Carroll, 1987) allows for unbiased estimation of the conditional volatility, while at the same time documents partial relations between price revisions and shocks to volume and open interest in line with the mixture of distributions model. ${ }^{8}$ Additionally, the range (high, low, open, close) of daily prices for the KOSPI200 Index futures contract is available, which allows us to test the volatility-volume relationship for different and usually more efficient volatility proxies. Range-based volatility estimators, such as the Garman-Klass and the log-Range, are used in this study due to their robustness when microstructure noise is present, high efficiency and information content if compared to ones using closing prices alone. ${ }^{9}$

The empirical results show that surprises in non-member (institutional, individual or foreign) investors' trading volume are positively associated with volatility. The results are even stronger when we use log-volume and generally consistent with the empirical findings of Daigler and Wiley (1999). One must recall that absolute price changes and volume are positively correlated due to the dispersion of beliefs caused by different interpretation of common information and the 'noisy' liquidity demand (Harris and Raviv, 1993; Shalen, 1993). As regards member institutional investors, we primarily find that unexpected volume is positively related to volatility. This result contradicts the informational advantage hypothesis and gives further support to the argument that trading by informed rational speculators can drive prices further away from fundamentals if their positive feedback strategies are followed by noise traders (Delong et al., 1990b). Interestingly, for long-run changes in non-member investors' trading volume, we show that non-member foreign (and institutional) investors decrease volatility, but non-member individuals exacerbate volatility, especially up to the period of the financial crisis. ${ }^{10}$ It seems that long-run changes in trading volume for non-member institutional and foreign investors are more value-motived or informative while long-run changes of non-member individuals trading are more market phase or momentum driven.

Another interesting result of this study is that the coefficients relating the unexpected component of open interest to volatility are negative which means that an increase in open interest during the day decreases the impact of a volume shock on volatility. However, when we allow for time to maturity effects, surprises in open interest are associated with more volatility near

\footnotetext{
${ }^{7}$ Open interest is the total number of outstanding contracts that are held by market participants at the end of each day. Trading volume usually depicts the pressure or intensity behind a price trend, while open interest measures the flow of money into the futures market. Using trading activity together with open interest would also help to distinguish between hedging and speculative trades. This is based on the argument that speculators are "day traders" who do not hold open positions overnight and, so, open interest at the close of trading primarily reflects hedging activity and possibly less informed trading. Consequently, trades that increase trading volume but do not increase open interest will be taken as speculative or more informed trades.

${ }^{8}$ According to the Mixture of Distributions Hypothesis (MDH), it is the arrival and intensity of new information that determines both price changes and volume (Clark, 1973; Epps and Epps, 1976; Tauchen and Pitts, 1983).

${ }^{9}$ Throughout the paper the word volatility would mean the variance of the logarithm of the (nearest maturity) index futures prices. The classical estimation procedure employs the squared (or absolute) difference between two consecutive closing prices, while the range- based one involves the squared difference between the high-low and open-close index future prices during a trading day.

${ }^{10}$ Long-run (and expected) changes in member investor trading volume also affect volatility negatively during the same period and when we account for value motivated trades (log-volume results).
} 
contract expiration. Potentially this is due to the wider price range over which less informed investors trade as the contract rolls to its expiration and information asymmetry rises. Finally, non-member institutional investors are not linked with any movement in volatility towards the maturity of the contract, while surprises in the trading activity of all other investors are still positively associated with volatility over the same period.

Section II of this paper reviews the volatility-volume relation implied by market microstructure and trader behavior models and provides some empirical evidence. Section III summarizes the data, while Section IV outlines the econometric model and estimation procedure that is used here. Section V provides the empirical results, and Section VI presents the conclusion of this paper.

\section{INFORMATION, VOLATILITY AND TRADING ACTIVITY}

\section{II.1 Mixture of Distributions Hypothesis}

The relation between volatility and volume has attracted a vast amount of theoretical and empirical research over the years. An early attempt to explain the volatility-volume relationship, without fully illustrating the information integration process, is due to Clark (1973), Epps and Epps (1976) and Tauchen and Pitts (1983). The mixture of distribution model posits a joint dependence of returns and volume on an underlying latent event or information flow variable such as the number of trades. Tauchen and Pitts (1983) model predicts a positive volatilityvolume relationship when the number of traders is fixed, while a negative relation is predicted when the number of traders is growing, such as the case of T-bills futures market. ${ }^{11}$ Tauchen and Pitts (1983) do not consider how traders form their reservation prices or what they learn from the market price, issues subsequently explored by Hindy (1994) and Andersen (1996). Andersen (1996) suggested a modified version of the mixture of distribution model under a competitive market framework in which informational asymmetries and liquidity needs motivate trade in response to the arrival of new information. The information flow is represented by a stochastic volatility process that drives the positive contemporaneous relationship between volatility and informed trading volume. $\mathrm{Li}$ and $\mathrm{Wu}$ (2006) suggest a version of the mixture of distributions model which allows liquidity trading to affect price volatility. They find that the positive relationship between volatility and volume is primarily associated with information arrivals by informed trading. In addition controlling for the effect of informed trading, return volatility is negatively correlated with volume, which is consistent with the contention that liquidity trading increases market depth and lowers price volatility. ${ }^{12}$

\footnotetext{
${ }^{11}$ In particular, they find that the variance of the daily price change and the mean daily trading volume depend upon three factors: the average daily rate at which new information flows to the market, the extent to which traders disagree when they respond to new information and the number of active traders in the market. Specifically, when the number of active investors is relatively stable it gives rise to a gently convex relationship between trading volume and volatility (new information arrival causes almost equal change in volume and volatility). As the market expands and more traders become aware of the market's possibilities, the relationship between volume and volatility flattens out towards a straight line (new information arrival causes a bigger change in volume than volatility).

${ }^{12}$ A market with higher liquidity-motivated trading volume tends to have more random buy and sell orders offsetting each other and, thus, causing no significant changes in prices. Moreover, liquidity trading absorbs the price impact of information-based trading and in this way higher intensity of liquidity trading helps lower volatility.
} 


\section{II.2 Information, Rational Expectations and Dispersion of Beliefs}

Market microstructure theory has associated price changes and trading volume with the arrival of new information in the markets. The theoretical models that have been proposed try to explain the process of price discovery and information assimilation that occurs under a market setting that allows for different types of traders distinguished by the quality of information they hold, the dispersion of expectations they form based on this information and their trading motives. In the Glosten and Milgrom (1985) model the process over which new information integrates into prices requires an understanding of how the specialist and other uninformed investors learn from observing market information. The trading process itself generates information which might be related to information on the underlying asset value. ${ }^{13}$

Much of the literature on how information incorporates into prices, and its signalling role focuses on rational expectations and dispersion of beliefs models. In rational expectations models, prices are affected both by private information and supply uncertainty (Grossman and Stiglitz, 1980). ${ }^{14}$ In dispersion of belief models, heterogeneous trader behavior can arise either because informed traders have different private information (Hindy, 1994) or because they simply interpret commonly known data in a different way (Harris and Raviv, 1993). ${ }^{15}$ Hindy (1994) suggests a model in the futures market which includes only informed traders who disagree in the interpretation of the private signals. He shows, using examples that this model is capable of producing expected volumes and price changes that are positively or negatively related for all time periods, or have a relation that changes from positive to negative or vice versa over time. Holthaussen and Verrecchia (1990) propose a partially revealing rational expectations model of competitive trading in which a heterogeneous interpretation of a public information release results in price and volume reactions. The extent to which the information content (informedness) of an information signal makes investors revise their beliefs in the same (consensus) or opposite direction gives rise to different volatility-volume relationships. More specifically, the variance of price changes and trading volume tend to be positively related when the informedness effect dominates the consensus effect and tend to be negatively related when the consensus effect dominates the informdness effect.

The models reviewed here provide a wealth of volatility-volume relationships. If investors have an information advantage (informed), due to access to market economic data it is likely to form homogenous expectations about the market movements, and the fundamental characteristics of an asset. Therefore, we would expect informed traders to buy and sell within a small range of prices around the fair value of the asset. Traders who do not have access to order flow data (less informed) cannot interpret with precision the noisy signals from volume and price changes, resulting in a wider dispersion of beliefs. ${ }^{16}$ Consequently, less informed investors are likely to

\footnotetext{
${ }^{13}$ For example a sequence of prices (Brown and Jennings, 1989; Grundy and McNichols, 1989) or trading volume (Blume et al., 1994; Schneider, 2009) can provide useful information to investors and hence affect the adjustment of prices to full information values.

${ }^{14}$ Wang (1994) suggested a model in which the uninformed investors cannot perfectly identify the informed investors' motive behind their trade and they face the risk of trading against informed investors' private information. The risk of information based trading also dictates that volume and absolute value of excess returns are positively correlated, reflecting the price movement necessary to induce uninformed traders to take the other side of the trade. He and Wang (1995) find that volume generated by new private signals and public announcements is always accompanied by large price changes while volume generated by existing private information is not. Pfleiderer (1984) shows a positive contemporaneous relation between volume and price changes; however, this result is entirely due to non-speculative trading because the correlation between speculative trading volume and absolute price changes is zero.

${ }^{15}$ It is not always clear how information obtained by traders relates to the ultimate value of the firm and hence not immediately apparent how unbiased or how valuable the information is.

${ }^{16}$ Shalen (1993) shows that the dispersion of beliefs measures both the excess volatility and excess volume of trade induced by the 'noisy' liquidity demand of futures hedgers. The intuition behind this is that when
} 
react to all changes in volume and price as it is difficult to differentiate short term liquidity (hedging) demand from changes in overall fundamental supply and demand.

\section{II.3 Noise Trading and Volatility}

The trading behavior associated with non-member investors is consistent with the noise literature (Black, 1986; DeLong et al., 1990a,1990b; Daigler and Wiley, 1999). Black (1986) argues that noise trading increases liquidity in the markets and also puts noise into the prices as they reflect both information and noise induced trading. DeLong et al. (1990a) show that the unpredictability of noise traders' beliefs creates excess risk and significantly reduces the attractiveness of arbitrage. In situations where arbitrageurs have short horizons, noise trading can lead to a large divergence between market prices and fundamental values. DeLong et al. (1990b) argue, despite the fact that rational speculation stabilizes prices, that trading by informed rational speculators can drive prices further away from fundamentals if it triggers positive feedback strategies by noise traders. ${ }^{17}$

II.3.1 Hypothesis. Member investors (securities companies here) represent the informed traders due to their direct access to the trading system. Members of the exchange enjoy lower trading costs and information advantages. ${ }^{18}$ This is in line with the argument that access to private information allows clearing members to better distinguish liquidity demand from fundamental information and to estimate current value more precisely, which translates into smaller dispersion of beliefs and less price volatility (Daigler and Wiley, 1999). If investors have an information advantage (informed), due to access to market economic data, it is likely to form homogenous expectations about market movements and the fundamental characteristics of an asset. Informed traders, are expected to buy and sell within a small range of prices around the fair value of the asset and, therefore, their trading is more likely to be associated with less volatile asset prices (information advantage hypothesis).

In this study, non-member investors (institutions, individual or foreign) are treated as uninformed or less informed because their orders are channeled through members' trading pits. They do not have direct access to the trading system and if they receive some information this happens on a delayed or a second hand basis. Less informed (or noise traders) are expected to have a greater dispersion of beliefs and to trade over a bigger range of prices relative to the fundamental value of the futures contract. Thus, we expect non-member investor trading to be associated with more volatility in the Korean index futures market.

On the occasion of public news announcements, expectations can be quite dispersed even among investors who have access to market economic data. One example of this is that financial analysts often have different opinions regarding future movements of interest rates and stock prices, despite the fact that all these analysts have access to the same economic data. In this case, we would expect to find a positive relationship even among informed investors' (unexpected) trading volume and volatility.

liquidity demand is uncertain speculators' estimates of future prices are dispersed since they cannot isolate private information, embedded in current prices, from hedging demands. Shalen also finds that the dispersion of expectations based on current information also contributes to the positive correlation between volume and absolute price changes.

${ }^{17}$ The key point is that, although part of the price rise is rational, part of it results from rational speculators' anticipatory trades and from positive feedback traders' reaction to such trades.

${ }^{18}$ Their direct access to the trading system provides them with short term information such as trading activity at specific prices and price trends. In addition they have specific information about their own customers' supply and demand in the cash and futures markets. Furthermore, they benefit from increased information in the cash markets because of their access to trading screens and in house knowledge in these markets. 


\section{II.4 Empirical Evidence}

A plethora of empirical studies have examined the relationship between volatility and volume in cash and futures markets and a positive contemporaneous relationship between the two variables is often documented (Karpoff, 1987; Gallant, Rossi and Tauchen, 1992; Bessembinder and Seguin, 1992). Bessembinder and Seguin (1993) find a strong positive relationship between contemporaneous volume (expected and unexpected) and volatility in eight futures markets, while the impact of an unexpected volume shock is between 2 and 13 times greater than the effect of changes in expected volume. They also find that the expected open interest is negatively related to volatility in all markets, a result consistent with the belief that variations in open interest reflect changes in market depth. Bessembinder and Seguin (1993) argue that the volatility-volume relationship might also depend on the class of traders after finding that trades resulting in changes in open interest appear to have a larger impact on prices than do trades that leave the open interest unaltered.

Daigler and Wiley (1999) investigate the impact of trader type on the futures volatilityvolume relationship. They find that the positive volatility-volume relationship is driven by the general public, a group of traders distant from the trading floor, less informed and with greater dispersion of beliefs. On the other hand clearing members and floor traders often decrease volatility and this is attributed mainly to the informational advantage from holding a seat in the futures market. In addition, Avramov et al. (2006) show that informed (or contrarian) trades lead to a reduction in volatility, while non-informational (or herding) trades lead to an increase in volatility. ${ }^{19}$ Bjønnes et al. (2007) also find that the volume-volatility relation depends on the group of market participants trading. Specifically, institutional investors' trading volume has the highest correlation with volatility, while trading by non-financial investors is not correlated with volatility at all. Bauwens et al. (2005) stresses the importance of private information in FOREX markets as a key determinant of volatility, the private information stemming primarily from the flow of orders between traders and their clients. Frommel et al. (2008) find that only larger sized order flows from financial customers and banks - indicating informed trading contribute to explaining exchange rate volatility, whereas flows from commercial customers do not.

In the case of KOSPI200 options, Ahn et al. (2008) find evidence that foreign investors are better informed compared to domestic investors and that domestic institutions have an edge in terms of information over domestic individuals. Ryu (2015) examines the information content of options and futures trades in the Korean Stock Exchange and finds that institutional futures trades are generally more informative than individual trades, and trades made by foreign institutions have the greatest permanent price impact.

\section{DATA DESCRIPTION}

We investigate the trader type effects on the volatility-volume relationship for the KOSPI200 index futures contract from the futures' market launch in 1996 until 2005, which seems adequate to capture changes in investment participation across investors. ${ }^{20}$ The dataset consists of daily data on high, low, open and closing prices of the KOSPI 200 Futures Index of the Korean

\footnotetext{
${ }^{19}$ Avramov et al. (2006) decompose sell trades into contrarian and herding trades. They conjecture that herding trades are uninformed and contrarian trades are informed using serial correlation tests. They demonstrate that when stock price declines, herding (sell) trades govern the increase in next period volatility and when stock price rises, contrarian trades lead to a decrease in next period volatility.

${ }^{20}$ Trading on a new market is initially very thin and the number of active investors is relatively small. As the market expands and traders become aware of the market's possibilities, the impact of different investors'
} 
Stock Exchange (KSE) from the 3 May 1996 (introduction of index futures) to 30 September 2005 (2308 observations). ${ }^{21}$ Furthermore, for the same period, daily trading volume of futures contracts bought and sold by eight different types of domestic investors and total open interest is available. ${ }^{22}$ Finally, daily trading volume data is also available for (non-member) foreign investors of the Korean stock exchange.

\section{III.1 Index futures volatility}

The returns for the futures contracts traded on the KOSPI200 index are defined as $R_{F, t}=$ $100 * \operatorname{Ln}\left(F_{t} / F_{t-1}\right)$, where $F_{t}$ is the price of the nearby index futures contract at time $t$. The prices of contracts with different maturity are not used to compute the returns at any time. For example, on the days when a rollover to the next expiration month occurs, we use the close-to-close return for the new nearby contract to avoid the distortion caused by calculating returns across contracts with different maturities. ${ }^{23}$ Here, index futures volatility would mean the variance of the logarithm of the (nearest maturity) index futures prices. The classical estimation procedure employs the squared (or absolute) difference between two consecutive closing prices, while the range-based one involves the squared difference between the high-low and open-close index future prices during a trading day. The intuition behind range-based volatility estimators is that in case, just by chance, the open and closing prices are close to each other when the security price has fluctuated substantially throughout the day, then the absolute or squared return will indicate low volatility. They are also found to be robust to microstructure noise and high in efficiency and information content (Garman and Klass, 1980; Beckers, 1983; Rogers and Satchell, 1991; Yang and Zhang, 2000). Parkinson (1980) proposed the use of the range for estimating volatility, while Garman and Klass (1980) combine the range with opening and closing prices to produce highly efficient volatility estimators. The Garman-Klass estimator used in this study is defined as

$$
\hat{\sigma}_{t}^{g k}=0.5\left[\operatorname{Ln}\left(\text { High }_{t}\right)-\operatorname{Ln}\left(\operatorname{Low}_{t}\right)\right]^{2}-[2 \operatorname{Ln}(2)-1]\left[\operatorname{Ln}\left(\text { Open }_{t}\right)-\operatorname{Ln}\left(\text { Close }_{t}\right)\right]^{2}
$$

where $\hat{\sigma}_{t}^{g k}$ is the Garman-Klass volatility, Ln is the natural logarithm and High, Low, Open, Close are the high, low, open and closing prices of the KOSPI200 Futures Index in the interval of a trading day. Brown (1990) argues that the opening and closing prices are highly influenced by microstructure effects and opposes their inclusion in estimators of volatility. Alizadeh (1998) reveals little theoretical efficiency gain from combining the range with the opening and closing prices. For this reason, the range is also used and estimated as

$$
\hat{\sigma}_{t}^{\text {range }}=\max \ln \left(F_{\tau}\right)-\min \ln \left(F_{\tau}\right)
$$

where $\tau=t-1, t-1+\frac{1}{n}, t-1+\frac{2}{n}, \ldots, t$ and $n$ denotes the number trades within a single trading day. The properties of the range-based estimator depend on the level of trading activity. This means that the smaller the sampling interval of the price path is, the more accurate the

trading on volatility becomes very important. In our study, the trading of individual and foreign investors on index futures increased significantly a few years after the market's lunch.

${ }^{21}$ The KOSPI 200, which is used as an underlying index for the futures contracts, is a market capitalization weighted index composed of 200 major stocks listed on the Korean Stock Exchange (KSE) and it represents about 80 percent of the total market capitalization of the KSE stock market.

${ }^{22}$ The Korean Stock Exchange publishes the daily amount of contracts traded by eight types of domestic investors and by foreign Investors. Domestic investors are categorized as institutional and individual investors. Moreover, domestic institutional investors consist of securities and non-securities companies. The latter are divided into insurance, investment, bank, merchant bank and mutual fund, pension fund and others.

${ }^{23}$ The contract months for futures are March, June, September and December, and the longest maturity period is one year. The last trading day of each contract is the second Thursday of each expiration month. The rollover schedule of the KOSPI 200 Index futures contract is two days before the last trading day. 
range-based volatility estimator will be. Alizadeh et al. (2002) argue in favor of using the range as volatility estimator as the return interval shrinks and discuss the very good performance of range-based volatility in the presence of microstructure noise. Andersen and Bollerslev (1998) show that the daily range is about as efficient as the realized volatility based on returns sampled every three-four hours. ${ }^{24}$ Shu and Zhang (2006) find that the range estimators are robust toward microstructure effects and quite close to the daily integrated variance (using 15minute squared returns). However, significant differences among various range estimators are detected if the asset return distribution involves an opening jump or a large drift. ${ }^{25}$ Range-based volatility measures are highly efficient and more suitable for the relationship we investigate. More specifically, if prices and volume are subordinate to the same latent information arrival processes (Tauchen and Pitts, 1983; Andersen and Bollerslev, 1997), range-based volatility proxies are better suited for volatility-volume studies as they contain sample path information. Finally, the use of different volatility estimators will provide additional robustness to our tradertype volatility-volume results. Range-based volatility proxies have been widely used in empirical finance research (Kawaller et al., 2001; Wang, 2002; Chen and Daigler, 2008).

\section{2 Trading volume}

A unique dataset which consists of trading volume for eight different types of domestic investors, foreign investors and open interest is used in this study. Trading volume is aggregated into four categories based on investor type (institutional vs individual) and access to the trading system (member vs non-member). Specifically, the four trader categories used here are member institutional (securities companies), non-member institutional (insurance, investment, bank, merchant banks and mutual fund, pension fund, other institutional investors), non-member individual and non-member foreign investors. Securities companies are members of the Korean Stock Exchange and they have direct access to the trading system. ${ }^{26}$ This gives an information advantage to this type of investors as they have up to the minute information about the supply and demand orders of the futures and cash markets. Daigler and Wiley (1999) argue that clearing members trade to benefit from mispricing of the futures contracts, as well as for long term hedging and arbitrage purposes.

Kodres and Pritsker (1997) show that many smaller insurance companies and pension funds are not members of the exchange they trade in, as their trading activity is insufficient to justify a seat. Non-member institutional investors, here, match this trader type and their trading volume is the sum of insurance, investment, bank, merchant banks and mutual fund, pension fund and

\footnotetext{
${ }^{24}$ Realized volatility is estimated as the sum of squared high-frequency returns or ranges over a given sampling period (e.g., five-minute returns) and is subject to microstructure biases due to uneven trading times, bid-ask bounces and stale prices (Andersen et al., 2001; Martens and van Dijk, 2007; Christensen and Podolskij, 2007).

${ }^{25}$ In a jump-diffusion model, the total variation of an asset return, also known as the quadratic variation, is the sum of the integrated variance and the jump variation. The integrated variance captures the variation emerging from the continuous (smooth) movements in the asset returns.

${ }^{26}$ Membership is granted only to the securities companies licensed by the Financial Supervisory Commission to conduct securities business, while no individual members are accepted. Members of the Korean Stock Exchange have the right to trade and the responsibility of clearing the trade. Access to the trading system is granted to the member firms only. Any members who have their own system, which is a client server interface for customers or multi-functioning system, can access the KSE system directly. Overseas brokers or dealers cannot access the Korean Stock Exchange system directly, but they can connect to a member's system located in Korea through international securities companies' global network. Foreigners who want to become a member of the KSE have to establish an office in Korea that is licensed as a securities company by the Financial Supervisory Commission. As of December 2005, the total number of KSE members stood at 90 of which 26 are foreign brokerage firms. All transactions in the KSE market are automatically processed and executed by the computerized trading system without the intervention of market makers.
} 
other institutional investors. ${ }^{27}$ Non-member institutional, foreign and individual traders have no access to temporary private information such as the order flow and, therefore, are less likely to affect prices in the spot and futures markets (Ito et al., 1998; Philips and Weiner, 1994). ${ }^{28}$ Based on the different trading motives and access to information, we would expect to find volatility-volume relationships that are not uniform across the different type of investors trading in the KSE futures market.

Table 1 reports descriptive statistics regarding the percentage breakdown of total volume (Panel A) into the four trader categories underlined above and the cross correlations (Panel B) between the identified trader categories. ${ }^{29}$ Average total trading volume increased significantly (from 0.61 to 23.41 trillion Korean won) over the nine-year period examined here. This immense increase in trading volume is not shared evenly across the different type of traders. Member institutional investors' average (daily) percentage of trading was 69.60 percent for the two years ending in 1997 and, thereafter, decreased gradually to 23.97 percent. As regards nonmember investors, individuals' percentage of trading volume increased after the crisis period and remained at high levels, of nearly 50 percent, until the end of the sample. The presence of foreign investors in the futures market also increased dramatically after the crisis, largely explaining the increase in total trading volume during 2004-2005. Finally, non-member institutional investors' participation never surpasses the threshold of 10 percent across the whole period. Panel B shows that trading activity correlations are the highest among non-member individuals (3) and member financial institutions (1), the two dominant investors in index futures across the sample. Moreover, the low correlation among investors' unexpected trading volume shows that investors respond similarly in terms of direction but differently in terms of size, when news arrive in the market, possibly due to the different trading motives and interpretation of information signals.

\section{ESTIMATION PROCEDURES}

The econometric techniques that we use in this paper are mainly parametric and consistent with previous studies that investigate the (contemporaneous) impact of trading volume on volatility (see Daigler and Wiley, 1999; Bessembinder and Seguin, 1992, 1993; Schwert, 1990). ${ }^{30}$ This procedure allows for unbiased estimation of the conditional daily return volatility, while at the same time accounting for effects such as the day of the week, the persistence of volatility, and lagged returns. In this model equation (1) estimates the conditional return based on lagged

\footnotetext{
${ }^{27}$ Their share of trading volume is small compared to member institutional investors and mainly they intend to trade for hedging and speculative purposes. The amount of information available to non-member investors in the Korean futures market is limited as anyone wishing to place an order is required to open an account for futures and options trading with a member firm.

${ }^{28}$ Bessembinder and Senguin (1993) argue that an unexpected change in open interest during the session is a close proxy for the current willingness of futures traders, in aggregate, to risk capital. Therefore, having temporary access to private information, such as trades that cause open interest changes or the amount of limit/market orders, can provide valuable information about the trader's risk aversion or willingness to risk capital.

${ }^{29}$ Wiley and Daigler (1998) examine the characteristics and relations among four categories of traders. They find that after scalpers, the general public trades most frequently and there are strong coincident correlations between pairs of groups such as scalpers, clearing members and the general public. Furthermore, they find that any information about prior days trading volume, both within and across trader categories, is useful for only a few days.

${ }^{30}$ This is also in agreement with the mixture of distribution model which predicts that volatility and volume are jointly determined by a latent information variable. Moreover, market microstructure models associate price and trading volume changes with access to information, expectations formed based on this information and trading motives. For example, Shallen (1993) finds that volatility and volume are related to the dispersion of expectations across traders which is mainly caused by the inability of (uninformed) investors to distinguish private information from the noisy liquidity demand.
} 
TABLE 1

Descriptive Statistics

Panel A: Average Trader Category Volume as a Percentage of Total Volume

\begin{tabular}{cccccr}
\hline Investor Type & Institutional (1) & Institutional (2) & Individual (3) & Foreign (4) & Total \\
\hline Period & & & & & \\
$1996-97$ & $69.60 \%$ & $4.33 \%$ & $23.19 \%$ & $2.88 \%$ & 0.6158 \\
$1998-99$ & $41.63 \%$ & $7.13 \%$ & $48.59 \%$ & $2.65 \%$ & 4.8226 \\
$2000-01$ & $33.49 \%$ & $10.09 \%$ & $49.76 \%$ & $6.66 \%$ & 8.1794 \\
$2002-03$ & $24.42 \%$ & $8.39 \%$ & $53.69 \%$ & $13.5 \%$ & 19.0362 \\
$2004-05$ & $23.97 \%$ & $6.37 \%$ & $47.11 \%$ & $22.55 \%$ & 23.4083
\end{tabular}

Panel B: Cross - Correlations between Trader Categories

\begin{tabular}{lcccccc}
\hline Series & $(1)-(2)$ & $(1)-(3)$ & $(1)-(4)$ & (2) - (3) & (2) - (4) & (3) - (4) \\
\hline Total & 0.828 & 0.858 & 0.769 & 0.821 & 0.739 & 0.804 \\
Moving Av. & 0.935 & 0.925 & 0.873 & 0.933 & 0.793 & 0.898 \\
Expected & 0.521 & 0.656 & 0.388 & 0.414 & 0.579 & 0.320 \\
Unexpected & 0.502 & 0.608 & 0.458 & 0.380 & 0.593 & 0.397 \\
\hline
\end{tabular}

This table presents daily volume descriptive statistics for four categories of investors. The categories are Member Institutional Investors (1), Non-member Institutional (2), Non-member Individual Investors (3) and Non-member Foreign Investors (4). Panel A shows trading volume by investor category and the total daily volume (in trillion Korean won). Percentages sum to 100 over each period. Panel B provides the cross correlations between each pair of volume variables. An ARMA $(0,10)$ model calculates the expected and unexpected trading volume components. ${ }^{31}$

returns, the day of the week and lagged volatility. Equation (2) estimates conditional volatility using transformations of past volatility, day of the week, and trading activity variables. Equation (3) transforms the lagged unexpected returns. The equations are:

$$
\begin{gathered}
R_{t}=a+\sum_{i=1}^{4} \rho_{j} d_{i}+\sum_{j=1}^{10} \gamma_{j} R_{t-j}+\sum_{j=1}^{10} \pi_{j} \hat{\sigma}_{t-j}+U_{t} \\
\hat{\sigma}_{t}=\delta+\sum_{i=1}^{4} \eta_{j} d_{i}+\sum_{j=1}^{10} \beta_{j} \hat{\sigma}_{t-j}+\sum_{j=1}^{10} \omega_{j} \hat{U}_{t-j}+\sum_{k=1}^{m} \mu_{k} A_{k}+e_{t} \\
\hat{\sigma}_{t}=\left|\hat{U}_{t}\right| \sqrt{\pi / 2}
\end{gathered}
$$

where $R_{t}$ is the percent change in the futures price on day $t ; d_{i}$ represent the four dummy variables for the days of the week; $\hat{\sigma}_{t}$ is the volatility on day $t$ and $A_{k}$ are the activity variables of volume

\footnotetext{
${ }^{31}$ We first construct a detrended activity series by deducting an equally weighted moving average of length 200 days from the original series. The detrended trading activity series are stationary for all trader types and open interest. Further, we partition the detrended activity series into expected and unexpected components using an $\operatorname{ARMA}(0,10)$ model. The ARMA $(0,10)$ model estimates the expected value using the 10-day moving average of the change in detrended volume. This is in agreement with the Bessembinder and Seguin (1993) who interpret the unexpected component of the detrended series as the daily activity shock and the expected component as activity that is forecastable but highly variable across days. We apply a 10 lag ARMA specification to be consistent with other studies. To further investigate alternative lag structures, we apply the Akaike and Schwarz information criteria finding that the expected and unexpected components are highly correlated with the corresponding 10 day lag estimates.
} 
and change in open interest. The residual $U_{t}$ represents unexpected returns. The transformed variable, $\left|\hat{U}_{t}\right| \sqrt{\pi / 2}$, has an expected value equal to the standard deviation of unexpected returns when they follow a normal distribution with a constant mean and time-varying standard deviation $\left(E\left(\left|\hat{U}_{t}\right|\right)=\sigma_{t}(2 / \pi)^{1 / 2}\right){ }^{32}$

In order to estimate the conditional volatility of the Korean index futures market, equations (1) and (2) are estimated using an iterative OLS procedure. First, we use daily close to close returns on the KOSPI200 index futures contract (with the nearest maturity) to estimate equation (1) without lagged volatility estimates. Second, the volatility transformation defined in equation (3) is applied to the residuals of equation (1) and using these transformed values we estimate equation (2). Third, the fitted volatility values from equation (2) are used to re-estimate equation (1). Finally, we re-estimate equation (2) with the residuals from the consistent estimation obtained from the second pass of equation (1). ${ }^{33}$

Lags of the estimated standard deviation series are included in equation (1) and (2) in order to capture the risk-return relationship and the persistence of volatility, respectively, over time. The estimation procedure in this paper shares similarities with the GARCH-in-mean model which is often used to investigate the relationship between risk and return or test for a time varying risk premium (Engle et al., 1986; French et al., 1987; Baillie and DeGennaro, 1990). Here, the coefficients $\pi_{j}$ measure the effect of higher volatility on future returns and are estimated using an iterative OLS method compared to the simultaneous maximum likelihood one of the GARCH-M model. ${ }^{34}$ Additionally, lagged raw residuals from (1) are included in equation (2) as it is evident from previous studies (Karpoff, 1987; Schwert, 1990) that they have explanatory power and they also allow for possible effects of recent realized returns on volatility. To be consistent with previous studies and incorporate the range of significant lags for each variable we set the number of lags $n$ equal to 10 in both equations. Further examination of different lag structures using information criteria leaves the results unaltered.

The trading activity variables $A_{k}$ in equation (2) are the expected and unexpected values of both the trader type volumes and the change in the contract's open interest. Trading activity variables are partitioned so we can investigate whether surprises in trading volume pass on more information and, therefore, have a larger effect on volatility than forecastable volumes. ${ }^{35}$ Further, including expected and unexpected components of open interest in equation (2) allows

\footnotetext{
${ }^{32}$ Evidence in Seguin (1991) indicates that the effect of changes in higher moments on inferences made using this class of volatility estimate are negligible for equity returns.

${ }^{33}$ Pagan (1984) and Murphy and Topel (1985) argue that regressions with generated regressors, such as (1), produce understated standard errors because the randomness in the predictions is ignored. In line with Pagan (1984), equation (1) is initially estimated without lagged volatility estimates, while after the first pass the process is iterated with several lags of $\widehat{\sigma}_{t}$, as instrumental variables, in estimating (1). This allows for valid inferences to be made and with only a small loss of efficiency. Pagan and Ullah (1988) also find that the errors-in-variables problem for estimating the true process for volatility is reduced when a parametric model for the risk term is used in combination with an instrumental variables approach.

${ }^{34}$ The iterative OLS estimator is unbiased if the conditional distribution of returns is normal (Davidian and Carroll, 1987; Schwert, 1990) and consistent with previous empirical research (Wang, 2002; Daigler and Wiley, 1999). A weighted least squares procedure suggested by Davidian and Carroll (1987), with fitted values from (2) used as weights for estimation of (1) was also estimated and conclusions remain the same.

${ }^{35}$ Several studies in the volume-volatility literature suggest detrending trading volume into expected and unexpected components. This separation allows us to examine the extent to which surprises versus trend activity affect the volatility-volume relationship. A number of detrending methods have been suggested in the literature depending on whether the underlying process is trend or stochastic stationary. As is evident from Table 1, the assumption of a constant growth rate for trader type volume seems quite restrictive. For this reason we employ a detrending procedure that allows for a stochastic trend component in volume, as well as an autocorrelated disturbance term similar to Andersen (1996). In other words, we filter out the trend in volume, while at the same time retaining the correlated deviations around this trend, which are often associated with increased information arrival intensity in market microstructure theory. Open interest is also partitioned into expected and unexpected components once we first deduct the moving average component.
} 
us to measure the sensitivity of volatility on a volume shock especially when a change in open interest occurs at the same time. ${ }^{36}$ For example, if the unexpected component of volume and open interest are positive and negative respectively, a trade that increases both volume and open interest has a smaller effect on volatility than a trade that increases volume but decreases open interest or leaves it unchanged. Table 1, panel B, shows that trading activities across trader types are highly correlated and this may make it difficult to disentangle between the volume effects of different traders. For this reason we repeat the analysis including only one trader type at a time and the conclusions remain the same on most occasions.

The inclusion of unexpected open interest and unexpected volume (not predetermined variables) in Equation (2) does not imply that volume shocks and changes in positions necessarily induce or cause (in either an economic or statistical sense) changes in prices. This paper is in accord with Clark (1973), Epps and Epps (1976), and Tauchen and Pitts (1983), who argue that volume and volatility are jointly endogenous variables that covary in response to external order or information shocks. The main econometric objective of this paper is to report partial relations between price revisions and shocks to volume and open interest, while conditioning on levels of recent activity. ${ }^{37}$ Specification (2) allows for this investigation.

We re-examine the volatility-volume relationship by individually substituting the GarmanKlass (1980) and High-Low range-based measures of volatility for $\hat{\sigma}_{t}$ in equations (1) and (2). Range-based volatility proxies are estimated using daily data on high, low, open, close of the nearest trading index futures contract. ${ }^{38}$ Since these measures calculate volatility independent of the return equation, we generate one pass estimation of equations (1) and (2). This is in line with previous research (Daigler and Wiley, 1999; Kawaller et al., 2001; Wang, 2007; Chen and Daigler, 2008; Kartsaklas and Karanasos, 2009) where Garman-Klass volatility is modelled as an autoregressive type process taking into account bidirectional feedback between volume and volatility, long memory characteristics and GARCH effects. ${ }^{39}$

\section{EMPIRICAL RESULTS}

\section{V.1 Volatility-volume relationship by trader category}

V.1.1 Raw volume results. Table 2 reports the results of regressing different measures of index futures volatility on trader type volume and open interest. Results are also reported for variables such as lagged returns, lagged volatility and day of the week dummies. Unexpected trading activity by member institutional investors is positively (and significantly) related with range-based volatility measures ( 5 percent). For non-member investors, institutional and

\footnotetext{
${ }^{36}$ Finally, we include open interest as a trading activity variable due to its association with the number of active informed traders. Bessembinder and Seguin (1993) argue in favor of using open interest in conjunction with volume data as it may provide insights into the price effects of market activity generated by informed versus uninformed traders or hedgers versus speculators.

${ }^{37}$ The expected component of trading volume reflects activity that is forecastable (but variable across days, while slower adjusting changes of this forecastable activity are captured by the moving average component.

${ }^{38}$ Range-based volatility measures are highly efficient and more suitable for the relationship we investigate. More specifically, if prices and volume are subordinate to the same latent information arrival processes (Tauchen and Pitts, 1983; Andersen and Bollerslev, 1997), range-based volatility proxies are better suited for volatility-volume studies as they contain sample path information.

${ }^{39} \mathrm{Chou}(2005)$ proposes a Conditional Autoregressive Range (CARR) model for the range (defined as the difference between the high and low prices).
} 
TABLE 2

Regressions of Volatility on Expected and Unexpected Volume by Trader Type

Volatility measures

\begin{tabular}{|c|c|c|c|}
\hline \multirow{2}{*}{ Regression coefficients } & & & \\
\hline & Return & Garman-Klass & High-Low \\
\hline Intercept & $0.691(4.21)^{* * *}$ & $0.085(2.71)^{* * *}$ & $0.071(6.55)^{* * *}$ \\
\hline \multicolumn{4}{|l|}{ KOSPI200 futures volume } \\
\hline \multicolumn{4}{|l|}{ Member Institutional Inv. } \\
\hline Moving average & $0.1244(0.60)$ & $0.039(1.08)$ & $0.016(1.33)$ \\
\hline Expected & $0.1259(0.64)$ & $0.030(0.67)$ & $0.007(0.48)$ \\
\hline Unexpected & $0.4495(2.12)^{* * *}$ & $0.177(4.75)^{* * *}$ & $0.088(7.07)^{* * *}$ \\
\hline \multicolumn{4}{|l|}{ Non-Member Institutional Inv. } \\
\hline Moving average & $-0.548(-1.83)^{* *}$ & $-0.124(-2.30)^{* * *}$ & $-0.037(-2.32)^{* * * *}$ \\
\hline Expected & $0.378(1.23)$ & $0.002(0.04)$ & $0.016(0.94)$ \\
\hline Unexpected & $0.312(2.10)^{* * *}$ & $0.049(2.01)^{* * *}$ & $0.030(3.39)^{* * *}$ \\
\hline \multicolumn{4}{|l|}{ Non-Member Individuals Inv. } \\
\hline Moving average & $0.342(1.44)^{*}$ & $0.065(1.62)^{* *}$ & $0.025(1.91)^{* * *}$ \\
\hline Expected & $-0.236(-0.68)$ & $0.011(0.18)$ & $-0.007(-0.38)$ \\
\hline Unexpected & $-0.417(-1.92)^{* * *}$ & $0.270(7.04)^{* * *}$ & $0.085(6.35)^{* * *}$ \\
\hline \multicolumn{4}{|l|}{ Non-Member Foreign Inv. } \\
\hline Moving average & $-0.424(-2.24)^{* * *}$ & $-0.089(-2.18)^{* * *}$ & $-0.040(-3.62)^{* * *}$ \\
\hline Expected & $-0.047(-0.43)$ & $-0.013(-0.64)$ & $-0.008(-1.23)$ \\
\hline Unexpected & $0.233(2.44)^{* * *}$ & $-0.033(-1.79)^{* *}$ & $-0.001(-0.22)$ \\
\hline \multicolumn{4}{|l|}{ KOSPI200 open interest } \\
\hline Moving average & $0.430(1.45)^{*}$ & $0.116(1.89)^{* * *}$ & $0.039(2.29)^{* * *}$ \\
\hline Expected & $0.166(0.41)$ & $0.084(0.99)$ & $0.004(0.19)$ \\
\hline Unexpected & $-0.369(-0.69)$ & $-0.214(-1.75)^{* *}$ & $-0.078(-2.27)^{* * *}$ \\
\hline Sum of 10 lagged volatilities & $0.693(128)^{* * *}$ & $0.739(84.2)^{* * *}$ & $0.760(427.5)^{* * *}$ \\
\hline Sum of 10 lagged unex. returns & $-0.191(6.89)^{* * *}$ & $-0.044(5.75)^{* * *}$ & $-0.008(3.83)^{* * *}$ \\
\hline Regression $\bar{R}^{2}$ & 0.239 & 0.347 & 0.463 \\
\hline
\end{tabular}

The following coefficients of equation (2) are reported: $\mu_{k}$, the sum of $\beta_{j}$ and the sum of $\omega_{j}$. Volumes are detrended by subtracting the 200-day centered moving average from each series prior to partitioning into expected and unexpected components using an ARMA $(0,10)$ model. Values in brackets are $t$-statistics for the hypothesis that the coefficient is zero using White (1980) heteroscedasticity consistent standard errors. Test statistics for 10 lagged coefficients are $F$-statistics for the hypothesis that the sum of the 10 coefficients is zero. Coefficients on raw volumes are scaled so the underlying unit is one trillion of Korean Won. *,**,*** denotes statistical significance at 0.15, 0.10, 0.05 level. Entire period results:1996-2005.

individual unexpected trading volumes are also positively associated with range-based volatilities. The largest effect on Garman-Klass volatility is attributed to non-member individuals $(0.270)$, while in the case of High-Low volatility it is shared between member institutional $(0.088)$ and non-member individual (0.085) investors. About surprises in non-member foreign investor trading, they are negatively associated with the range-based volatilities and only marginally significant (at 10 percent) for the Garman-Klass estimator. In the case of return standard deviation, we observe a positive link between return volatility and unexpected trading volume of member institutional investors. The positive effect on volatility is also shared between non-member institutional and foreign investors. Interestingly, it is the non-member individuals' unexpected component which affects return volatility negatively $(-0.417)$. 
Surprises in open interest are often accompanied with lower volatility (negative relation). ${ }^{40}$ In other words, unexpected changes in open interest reduce the sensitivity of volatility to volume, especially when a trade increases both trading volume and open interest. The expected component of trading activity is insignificant across all trader types and volatility estimators and the corresponding results are not analysed further.

Changes in the moving average component of member institutional investors do not affect volatility. On the other hand, non-member institutional and foreign investors trading affect volatility negatively. This indicates that slowly increasing trading volumes, for these trader types, reduce volatility in the futures market. The trend component of non-member individuals' trading is positively associated with volatility. These results are robust across volatility proxies and even more significant in the case of range-based ones. Including open interest as an activity variable in the volatility regressions is also supported by significant and positive coefficients on the moving average component.

We further examine whether the trader type effects on volatility are robust to the Asian financial crisis that hit the major Asian economies in the summer of 1997 and lasted until the end of the same year. Another reason for investigating the after crisis period is that non-member investors significantly increased their participation in futures trading. For example, non-member individual and foreign investors almost doubled their trading in the after crisis period (see descriptive statistics in Table 1). Table 3 reports the results of regressing volatility on volume excluding the period from the start of the sample until the end of 1997 (388 observations).

As is evident in Table 3, the unexpected components of trading volume remain highly significant and of the same sign compared to the whole sample. In particular, surprises in trading activity are positively correlated with range-based volatility in the case of member institutional, non-member institutional and individual investors. Surprises in non-member foreign investors' volume no longer affect range-based volatility. Results for the return standard deviation regression remain the same. Member institutional investors are the most dominant ( $0.479 \mathrm{vs} .0 .313 \mathrm{vs}$. 0.249 ) among those who share a positive effect on return volatility, while non-member individuals affect volatility negatively $(-0.314)$, although somewhat less significantly. The expected components of trading activity and open interest are still insignificant.

An important change is documented in the moving average component of all investors trading activity after the Asian financial crisis. All the coefficients become insignificant showing no relation between long-run changes in trader type volume and volatility. The moving average component of open interest is now significant (at 10 percent) but turns into negative. In other words, long-run changes in open interest, after the crisis, are associated with lower volatility and increased informativeness. The after crisis results for the unexpected components of trading volume and open interest are robust across the different types of investors and volatility estimators. Unexpected changes in open interest are still negative and significant.

Overall, we find that unexpected levels of volume and open interest are more important in explaining volatility than expected and moving average components. This property is quite robust across the different trader types, volatility estimators, and the different sample periods examined. Member investors' unexpected trading volume exhibits a positive relation with volatility. This result indicates that access to temporary private information, like the order flow, does not help member institutional investors to trade within a smaller range of prices. Our finding is more in agreement with dispersion of beliefs models on the occasion of public news announcements and, Delong et al. (1990b), who argue that trading by informed rational speculators can drive prices further away from fundamentals if it triggers positive feedback

\footnotetext{
${ }^{40}$ The results are similar across the different volatility proxies. However, their significance changes slightly as we move from one volatility estimator to the other.
} 
TABLE 3

Regressions of Volatility on Expected and Unexpected Volume by Trader Type

Volatility measures

\begin{tabular}{|c|c|c|c|}
\hline Regression coefficients & Return & Garman-Klass & High-Low \\
\hline Intercept & $1.608(7.19)^{* * *}$ & $0.190(6.04)^{* * *}$ & $0.128(8.59)^{* * *}$ \\
\hline \multicolumn{4}{|l|}{ KOSPI200 futures volume } \\
\hline \multicolumn{4}{|l|}{ Member Institutional Inv. } \\
\hline Moving average & $-0.126(-0.59)$ & $-0.003(-0.09)$ & $0.001(0.15)$ \\
\hline Expected & $0.233(0.89)$ & $0.030(0.71)$ & $0.0125(0.81)$ \\
\hline Unexpected & $0.479(2.29)^{* * *}$ & $0.148(4.30)^{* * *}$ & $0.079(6.51)^{* * *}$ \\
\hline \multicolumn{4}{|l|}{ Non-Member Institutional Inv. } \\
\hline Moving average & $-0.231(-0.81)$ & $-0.054(-1.17)$ & $-0.013(-0.85)$ \\
\hline Expected & $0.440(1.45)^{*}$ & $0.009(0.19)$ & $0.019(1.13)$ \\
\hline Unexpected & $0.313(2.10)^{* * *}$ & $0.066(2.89)^{* * *}$ & $0.033(3.66)^{* * *}$ \\
\hline \multicolumn{4}{|l|}{ Non-Member Individuals Inv. } \\
\hline Moving average & $-0.156(-0.65)$ & $-0.047(-1.26)$ & $-0.014(-1.08)$ \\
\hline Expected & $0.131(0.38)$ & $0.048(0.91)$ & $0.015(0.84)$ \\
\hline Unexpected & $-0.314(-1.43)^{*}$ & $0.252(6.91)^{* * *}$ & $0.086(6.52)^{* * *}$ \\
\hline \multicolumn{4}{|l|}{ Non-Member Foreign Inv. } \\
\hline Moving average & $0.153(0.75)$ & $0.029(0.84)$ & $0.004(0.34)$ \\
\hline Expected & $-0.070(-0.64)$ & $-0.021(-1.06)$ & $-0.011(-1.67)^{* *}$ \\
\hline Unexpected & $0.249(2.64)^{* * *}$ & $-0.017(-0.99)$ & $0.001(0.23)$ \\
\hline \multicolumn{4}{|l|}{ KOSPI200 open interest } \\
\hline Moving average & $-0.588(-1.85)^{* *}$ & $-0.087(-1.67)^{* *}$ & $-0.034(-1.81)^{* *}$ \\
\hline Expected & $-0.132(-0.33)$ & $0.040(0.55)$ & $-0.004(-0.17)$ \\
\hline Unexpected & $-0.472(-0.92)$ & $-0.284(-2.61)^{* * *}$ & $-0.089(-2.67)^{* * *}$ \\
\hline Sum of 10 lagged volatilities & $0.407(28.2)^{* * *}$ & $0.591(82.9)^{* * *}$ & $0.614(183.3)^{* * *}$ \\
\hline Sum of 10 lagged unex. returns & $-0.091(1.55)$ & $-0.020(1.79)$ & $-0.008(3.36)^{* *}$ \\
\hline Regression $\bar{R}^{2}$ & 0.202 & 0.393 & 0.492 \\
\hline
\end{tabular}

The following coefficients of equation (2) are reported: $\mu_{k}$, the sum of $\beta_{j}$ and the sum of $\omega_{j}$. Volumes are detrended by subtracting the 200-day centered moving average from each series prior to partitioning into expected and unexpected components using an ARMA $(0,10)$ model. Values in brackets are $t$-statistics for the hypothesis that the coefficient is zero using White (1980) heteroscedasticity consistent standard errors. Test statistics for 10 lagged coefficients are $F$-statistics for the hypothesis that the sum of the 10 coefficients is zero. Coefficients on raw volumes are scaled so the underlying unit is one trillion of Korean Won. *,**,*** denotes statistical significance at $0.15,0.10,0.05$ level. After crisis results:1998-2005.

strategies by noise traders. Further, we find that surprises in non-member investors' trading volume are positively associated with volatility in most of the cases. This result is consistent with Daigler and Wiley (1999) who find that the positive volatility-volume relationship is driven by the general public or less informed investors. In this study we consider non-member investors as less informed due to the fact that they do not have direct access to the trading system. The coefficients relating the unexpected component of open interest with volatility are negative, implying that an increase in open interest during the day lessens the impact of a volume shock in volatility. This is in accordance with the Bessembinder and Seguin (1993) results, who also find a negative relation between surprises in open interest and volatility. Furthermore, the after crisis period has a significant impact on the moving average components of non-member investors and open interest. In particular, non-member foreign (and institutional) investors trend activity 
seems to increase volatility for the entire period but when the crisis period is excluded all moving average coefficients become insignificant.

As regards the other variables included in the regression, lagged volatilities are significant and range from 0.693 to 0.760 for the whole sample and from 0.407 to 0.614 for the after crisis period. Lagged unexpected returns are negative and significant in four out of six instances. ${ }^{41}$ Finally, the explanatory power of the volatility-volume regressions is substantially higher for the High-Low $(0.463,0.492)$ and Garman-Klass volatility $(0.347,0.393)$ estimators compared to the return volatility ones $(0.239,0.202)$.

V.1.2 Log volume results. Further, we have investigated the effect of the number of active value motivated traders by considering the natural logarithm of trader type volume (see Appendix for more details). This alternative specification of trading volume helps with the interpretation of surprises in trading activity as the percentage deviations from trend. The positive relationship between volatility and surprises in non-member investors' trading volume is reinforced, with individuals being the most active in the case of range-based volatility and foreigners in the case of return volatility. These results are also consistent with Jones et al. (1994), who find that public, rather than private, information is the major source of short-term volatility. Interestingly, the effect of member investors trading activity becomes much less significant and of different sign across volatility estimators. The effect of unexpected open interest on volatility remains negative and significant.

Regarding the trend component of non-member individual and foreign investors, a positive and negative effect on volatility is documented, respectively, especially during the crisis period. It is worth mentioning the uniformly positive and significant relationship between volatility and the expected component of non-member individuals, as well as the negative and significant relationship between volatility and the trend component of non-member foreign investors' trading volume. Finally, the explanatory power of the volatility-volume regressions has improved significantly when we use the natural logarithm of trading activity. For example, the explanatory power of the log-volume regressions in the after crisis period is $0.256,0.482$ and 0.592 for the return, Garman-Klass and High-Low volatility estimators, respectively.

V.1.3 Time-to-maturity effects. In this section, we investigate whether trader type behaviour changes around the expiration of the futures contract by adding a constant and trading volume slope dummies in the volatility regression. ${ }^{42}$ The constant dummy in the regression would allow us to test whether a pattern known as the 'Samuelson' effect is evident. ${ }^{43}$ Alternative theories to the 'Samuelson' effect, such as the state variable effect (Richard and Sundaresan, 1981; Andersen and Danthine, 1983) and the speculative effect (Hong, 2000), allow for more rich

${ }^{41}$ The results for the daily dummy variables (not reported) reveal that, for return volatility, Monday and Tuesday are both positive and significant, while, for the range-based volatility proxies, it is only during Tuesdays that the market experiences increased volatility.

${ }^{42}$ The model is extended by adding constant and slope dummy variables as follows

$$
\hat{\sigma}_{t}=\delta+d_{\exp }+\cdots+\sum_{k=1}^{m} \mu_{k} A_{k}+\sum_{k=1}^{m} \mu_{k}\left(d_{\exp } \times A_{k}\right)+e_{t}
$$

where $d_{\exp }$ is a dummy variable that takes the value of 1 for the two weeks (and the weekdays) before the expiration day and zero otherwise. For robustness, we have also used a dummy which takes the value of 1 for the week (and the weekdays) before the expiration day. The results from this regression are not qualitatively different from those reported in table $4 \mathrm{~b}$.

${ }^{43}$ Samuelson (1965) shows that the return volatility of a futures contract monotonically rises as the contract expires. This is mainly a price elasticity effect because when the futures contract approaches its expiration, its price elasticity to market shocks increases and, therefore, its volatility rises. 
time-to-maturity patterns in futures return volatility. ${ }^{44}$ The trading volume slope dummies will help to examine whether the near maturity patterns in volatility can be explained by trader type behaviour. The variation in information asymmetry that affects the term structure of futures return volatility is also an important determinant of open interest according to Hong (2000). ${ }^{45}$ Thus, the relation between open interest and volatility (near contract expiration) will provide important evidence on the ability of the market to absorb trading volume shocks toward contract maturity.

A comparison of Table $4 \mathrm{a}$ and 2 shows that all changes in volume (unexpected) coefficients are significant at 5 percent level with same sign. This implies that the introduction of dummy variables does not fundamentally change the volatility-volume relationships during normal times. For example, the unexpected coefficients of both member financial institutions and non-member are nearly equal when 2 is compared with $4 \mathrm{a}$, indicating that there is no organic difference in trading behavior (proxied by changes in activity here). A deep sensitivity in the volatility-volume behavior is observed for both non-member institutional and non-member individual investors, as the coefficients are three $(0.910 / 0.312)$ and two times $(-0.820 /-0.417)$ higher respectively, implying that changes in (unexpected) volume are more pronounced. For member institutional investors, the volatility-volume relationships remain highly significant and positive across all volatility estimators, while the unexpected component of open interest is still negatively associated with volatility. Finally, the moving average coefficients have become less significant for some trader types (non-member institutional and foreign) and not significant for others (non-member individual and open interest) in the case of range-based volatilities. ${ }^{46}$

We now compare trader-type behavior near the expiration (Table 4b) of the futures contract with that during normal times (Table 4a). The slope dummy coefficients for member institutional, non-member individual and foreign investors' (unexpected) volume are insignificant showing no change in their trading behavior (or volatility-volume link) near contract maturity. In contrast, Table $4 \mathrm{~b}$ shows an entirely different result for non-member institutional investors. Their unexpected coefficients are still significant at 5\% level but turn into negative $(-0.950$, $-0.115,-0.043)$ from the positives ones $(0.910,0.111,0.060)$ evidenced in Table $4 a$, which indicates that the behavior of non-member institutional has fundamentally changed during the time-to-maturity. In other words, the combined effect shows that volatility changes are less likely to be affected by the trading of non-member institutional investors as the contract rolls to its expiration. The term structure of stock index futures prices is mainly driven by interest rate and dividend levels and, thus, the information sets of investors across the different maturities should be similar. Heterogeneous trader behavior, though, can arise even when traders simply interpret commonly known data in a different way, especially near contract expiration.

Another interesting result is that the slope coefficients which link unanticipated open interest and volatility turn into positive $(3.798,0.754,0.316)$ and highly significant (5 percent),

\footnotetext{
${ }^{44}$ Hong (2000), allowing for differently informed investors and nonmarketed risks, argues that as the futures contract rolls to its expiration date, its sensitivity to the non-marketed risks increases and uninformed investors can learn less about the fundamental, so information asymmetry rises. Therefore, less private information is impounded into the futures price and so, all else being equal, the futures price moves less as the contract expires.

${ }^{45}$ Hong (2000) shows that open interest can take on rich time-to-maturity patterns, based on the fact that the higher the adverse selection cost taken by uninformed investors, when they trade with informed investors, the lower the open interest will be. Milonas (1986) examines the time-to-maturity pattern of open interest for different futures markets and finds that the very distant and nearest contracts have the least open interest, probably due to their high illiquidity. Further, the author finds that for the liquid contracts of intermediate maturities, different time-to-maturity patterns can also arise, with more distant contracts having more or less open interest than those nearer to the expiration.

${ }^{46}$ Interestingly, in the case of return volatility the significant moving average coefficients of Table 2 have been replaced with significant expected components for all non-member investors (in Table 4a).
} 
TABLE $4 \mathrm{a}$

Regressions of Volatility on Expected and Unexpected Volume by Trader Type

Volatility measures

\begin{tabular}{|c|c|c|c|}
\hline \multirow{2}{*}{ Regression coefficients } & & & \\
\hline & Return & Garman-Klass & High-Low \\
\hline Intercept & $0.717(4.36)^{* * *}$ & $0.088(2.91)^{* * *}$ & $0.072(6.62)^{* * *}$ \\
\hline \multicolumn{4}{|l|}{ KOSPI200 futures volume } \\
\hline \multicolumn{4}{|l|}{ Member Institutional Inv. } \\
\hline Moving average & $0.124(0.52)$ & $0.055(1.21)$ & $0.023(1.63)^{* *}$ \\
\hline Expected & $-0.151(-0.53)$ & $-0.020(-0.42)$ & $-0.015(-0.93)$ \\
\hline Unexpected & $0.470(2.02)^{* * *}$ & $0.167(3.79)^{* * *}$ & $0.086(6.13)^{* * *}$ \\
\hline \multicolumn{4}{|l|}{ Non-Member Institutional Inv. } \\
\hline Moving average & $-0.443(-1.28)$ & $-0.102(-1.67)^{* *}$ & $-0.032(-1.76)^{* *}$ \\
\hline Expected & $0.818(2.31)^{* *}$ & $0.033(0.59)$ & $0.038(1.96)^{* * *}$ \\
\hline Unexpected & $0.910(4.37)^{* * *}$ & $0.111(3.43)^{* * *}$ & $0.060(5.24)^{* * *}$ \\
\hline \multicolumn{4}{|l|}{ Non-Member Individuals Inv. } \\
\hline Moving average & $0.359(1.26)$ & $0.036(0.76)$ & $0.020(1.36)$ \\
\hline Expected & $-0.639(-1.67)^{* *}$ & $0.005(0.09)$ & $-0.016(-0.81)$ \\
\hline Unexpected & $-0.820(-3.18)^{* * *}$ & $0.254(5.74)^{* * *}$ & $0.070(4.74)^{* * * *}$ \\
\hline \multicolumn{4}{|l|}{ Non-Member Foreign Inv. } \\
\hline Moving average & $-0.291(-1.29)$ & $-0.074(-1.41)^{*}$ & $-0.031(-2.43)^{* * *}$ \\
\hline Expected & $0.248(1.75)^{* *}$ & $0.027(0.85)$ & $0.009(0.99)$ \\
\hline Unexpected & $0.293(2.43)^{* * *}$ & $-0.022(-0.82)$ & $0.002(0.25)$ \\
\hline \multicolumn{4}{|l|}{ KOSPI200 open interest } \\
\hline Moving average & $0.231(0.64)$ & $0.083(1.12)$ & $0.026(1.23)$ \\
\hline Expected & $0.087(0.17)$ & $0.057(0.51)$ & $0.001(0.03)$ \\
\hline Unexpected & $-0.503(-0.84)$ & $-0.279(-1.82)^{* *}$ & $-0.094(-2.33)^{* * *}$ \\
\hline Sum of 10 lagged volatilities & $0.695(127.1)^{* * *}$ & $0.740(83.3)^{* * *}$ & $0.761(423.1)^{* * *}$ \\
\hline Sum of 10 lagged unex. returns & $-0.188(6.67)^{* * *}$ & $-0.044(5.83)^{* * *}$ & $-0.008(3.78)^{* * *}$ \\
\hline Regression $\bar{R}^{2}$ & 0.249 & 0.352 & 0.472 \\
\hline
\end{tabular}

The following coefficients of equation (2) are reported: $\mu_{k}$, the sum of $\beta_{j}$ and the sum of $\omega_{j}$. Volumes are detrended by subtracting the 200-day centred moving average from each series prior to partitioning into expected and unexpected components using an ARMA $(0,10)$ model. Values in brackets are $t$-statistics for the hypothesis that the coefficient is zero using White (1980) heteroscedasticity consistent standard errors. Test statistics for 10 lagged coefficients are $F$-statistics for the hypothesis that the sum of the 10 coefficients is zero. Coefficients on raw volumes are scaled so the underlying unit is one trillion of Korean Won. *,**,*** denotes statistical significance at 0.15, 0.10, 0.05 level. Entire period results:1996-2005.

indicating that open interest shocks are accompanied with bigger price movements towards the end of the contract life. This also shows that new position openings in the futures market (two weeks) before expiration appear to be stirring up the market rather than making it more informative as it happens during normal times. ${ }^{47}$ The slope dummy on expected volume is negative (and significant) for foreign investors, but positive (and significant) for member institutional investors. This indicates that trading volume, forecastable across days, exacerbates (or alleviates) volatility as the contract rolls to its expiration for these trader types. Finally, the constant dummy coefficient is negative and significant which shows that range-based (Garman-Klass, High-Low) volatility decreases near contract expiration.

\footnotetext{
${ }^{47}$ This is also consistent with the above theories that allow for more rich time-to-maturity patterns in futures return volatility and open interest.
} 
TABLE $4 \mathrm{~b}$

Time-to-maturity effects

Volatility measures

\begin{tabular}{lccc}
\cline { 2 - 4 } Regression coefficients & Return & Garman-Klass & High-Low \\
\hline Intercept & $-0.164(-1.23)$ & $-0.037(-1.62)^{* *}$ & $-0.012(-1.61)^{* *}$ \\
KOSPI200 futures volume & & & \\
Member Institutional Inv. & & & \\
$\quad$ Moving average & $0.226(0.47)$ & $-0.013(-0.19)$ & $-0.013(-0.52)$ \\
$\quad$ Expected & $1.105(1.53)^{*}$ & $0.276(2.48)^{* * *}$ & $0.114(2.87)^{* * *}$ \\
$\quad$ Unexpected & $-0.111(-0.22)$ & $0.063(0.81)$ & $0.013(0.47)$ \\
Non-Member Institutional Inv. & & \\
$\quad$ Moving average & $-0.633(-0.90)$ & $-0.126(-0.99)$ & $-0.027(-0.72)$ \\
Expected & $-1.345(-1.74)^{*}$ & $-0.112(0.98)$ & $-0.098(-2.27)^{* * *}$ \\
$\quad$ Unexpected & $-0.950(-3.25)^{* * *}$ & $-0.115(-2.44)^{* * *}$ & $-0.043(-2.58)^{* * *}$ \\
Non-Member Individuals Inv & & & \\
$\quad$ Moving average & $0.164(0.29)$ & $0.131(-1.25)$ & $0.021(0.63)$ \\
Expected & $0.746(0.90)$ & $-0.067(-0.54)$ & $0.005(0.12)$ \\
$\quad$ Unexpected & $0.464(0.91)$ & $-0.065(0.65)$ & $-0.004(-0.12)$ \\
Non-Member Foreign Inv. & & & \\
Moving average & $-0.351(-0.92)$ & $-0.051(-0.82)$ & $-0.016(-0.78)$ \\
Expected & $-0.536(-2.07)^{* * *}$ & $-0.107(-2.38)^{* * *}$ & $-0.044(-2.79)^{* * *}$ \\
$\quad$ Unexpected & $0.062(0.35)$ & $-0.001(-0.01)$ & $0.005(0.42)$ \\
KOSPI200 open interest & & & \\
$\quad$ Moving average & $0.361(0.58)$ & $0.042(0.43)$ & $0.021(0.58)$ \\
Expected & $0.008(0.01)$ & $0.051(0.25)$ & $-0.023(-0.35)$ \\
Unexpected & $3.798(2.68)^{* * *}$ & $0.754(2.96)^{* * *}$ & $0.316(3.82)^{* * *}$ \\
\hline
\end{tabular}

In general, there is no evidence that (unexpected) trading activity across traders affects volatility differently when the slope dummies are added, while significance increases considerably for some trader types. Furthermore, moving average coefficients have become less significant for some trader types and not significant for others including open interest. When we consider time-to-maturity effects, non-member institutional trading becomes much less associated with volatility as the contract rolls to its expiration indicating a change in investment behavior. Surprises in open interest during the day are correlated with much bigger price movements near the expiration of the contract, indicating that volatility becomes more sensitive to volume shocks especially when trades result in an increase on open interest as well. Near contract expiration, the expected component of foreign and non-member institutional trading exacerbates and alleviates range-based (High-Low, Garman-Klass) volatility, respectively. ${ }^{48}$ Finally, the explanatory power of the trading activity and other variables in the volatility regressions is almost the same and consistent with the evidence in Table $2 .^{49}$

\footnotetext{
${ }^{48}$ The constant dummy coefficients also show that range-based volatility, either High-Low or GarmanKlass, decreases as the contract rolls toward expiration.

${ }^{49}$ The other variables included in the volatility regressions, such as lagged volatilities, lagged unexpected returns and day dummies, are also very significant and of the same sign and magnitude compared to the values in Table 2 .
} 


\section{CONCLUSIONS}

This study provides empirical evidence on the volatility-volume relationship for different trader types of the Korean index futures market. The different types of traders have been selected according to the information they possess and their access to the trading system. The trading activity variables are also partitioned into expected and unexpected components, while the econometric techniques that we use allow for an unbiased estimation of daily standard deviations conditional on the trading activity variables, day of the week, lagged volatilities and lagged unexpected returns.

Overall, we find that member institutional investors' unexpected trading volume exhibits a positive relation with volatility. This indicates that access to temporary private information, like the order flow, does not help member institutional investors to better distinguish liquidity demand from fundamental information. Our finding is more in agreement with dispersion of beliefs models on the occasion of public news announcements and, Delong et al. (1990b), who argue that trading by informed rational speculators can drive prices further away from fundamentals if it triggers positive feedback strategies by noise traders. Moreover, we find that surprises in non-member (institutional, individual, and foreign) investors' trading volume are also positively associated with index futures volatility. This supports the hypothesis that traders with no access to order flow data (or less informed) cannot differentiate short-term liquidity demand from the volume associated with change in fundamentals. Recall Daigler and Wiley's (1999) finding that the positive volatility-volume relationship is driven by the general public or less informed investors. We also observe a uniformly negative relationship between volatility and unexpected changes in open interest. This implies that increase in open interest during the day reduce the impact of a volume shock in volatility. Bessembinder and Seguin (1993) also report a negative relation between surprises in open interest and volatility. Although for the whole sample we report very significant relations between long-run changes in non-member investors' trading volume and volatility, after the financial crisis, all these relations become insignificant. We find that non-member foreign (and institutional) investors' trading is negatively associated with volatility but non-member individuals exacerbate prices, especially up to the period of the financial crisis. ${ }^{50}$ Interestingly, long-run changes in trading volume for non-member foreign (and institutional) investors seem to be value-motived or informative while long-run changes of non-member individuals trading are market phase or momentum driven. Overall, surprises in trading volume and open interest are more important in explaining volatility than expected and moving average components. This result is robust across different types of traders, volatility estimators and sample periods.

We also investigated the volatility-volume relationship as the futures contract roll to its expiration by adding trading volume slope dummies near the expiration date. The results reveal that non-member institutional investors trading is not associated with volatility as the futures contract moves towards maturity, while there is no change in trading behaviour for the remaining investors. Regarding surprises in open interest, they are associated with much bigger price movements near the expiration of the contract, indicating that volatility becomes more sensitive to volume shocks especially when trades result in an increase on open interest at the same time. This result is also consistent with theories that allow for more rich time-to-maturity patterns in futures return volatility and open interest (Richard and Sundaresan, 1981; Andersen and Danthine, 1983; Hong, 2000). ${ }^{51}$ In other words, the issue of new futures contracts (two weeks)

\footnotetext{
${ }^{50}$ When we take into account value motivated traders (log volume results), the expected and moving average trading of member investors affects volatility negatively during the same period.

${ }^{51} \mathrm{Hong}(2000)$ arhues that as the futures contract rolls to its expiration date, its sensitivity to nonmarketed risk shocks increases and uninformed investors can learn less about the fundamental by looking at prices.
} 
before expiration appear to be stirring up the market rather than making it more informative as it happens during normal times.

The inclusion of variables such as lagged volatilities and unexpected returns in the volatility regressions are significant in most of the cases, with the effect of lagged unexpected returns being consistently negative. Furthermore, we find that when the high-low volatility measure is used, models that incorporate trader type volume, lagged volatilities and unexpected returns can explain up to 59 percent of the variability in volatility. The high explanatory power of trading volume in the volatility regression, when a range based estimator is used as a volatility proxy, indicate that there is a close correspondence between trading activity and volatility. If prices and volume are subordinated to the same latent information arrival process, range based volatility proxies may be well suited for volatility-volume studies as they contain sample path information.

\section{REFERENCES}

Admati, A. and Pfleiderer, P. (1988). 'A Theory of intraday patterns: Volume and price variability', Review of Financial Studies, 1, pp. 3-40.

Ahn, H-J., Kang, J. and Ryu, D. (2008). 'Informed trading in the index option market: The case of KOPSI200 options', Journal of Futures Markets, 28, pp. 1118-46.

Alizadeh, S. (1998). 'Essays in financial econometrics', Ph.D. Dissertation, Department of Economics, University of Pennsylvania.

Alizadeh, S., Brandt, M. and Diebold, F. (2002). 'Range-based estimation of stochastic volatility models', Journal of Finance, 57, pp. 1047-91.

Andersen, T. (1996). 'Return volatility and trading volume: an information flow interpre- tation of stochastic volatility', Journal of Finance, 1, pp. 169-204.

Andersen, T. and Bollerslev, T. (1996). 'Heterogeneous information arrivals and return volatility dynamics: Uncovering the long-run in high frequency returns', Journal of Finance, 52, pp. 975-1005.

Andersen, T. and Bollerslev, T. (1998). 'Answering the skeptics: Yes, standard volatility models do provide accurate forecasts', International Economic Review, 39, pp. 885-905.

Andersen, T., Bollerslev, T., Diebold, F. and Ebens, H. (2001). 'The distribution of realized stock return volatility', Journal of Financial Economics, 61, pp. 43-76.

Andersen, R. and Danthine, J. (1983). 'The time pattern of hedging and the volatility of futures prices', Review of Economic Studies, 50, pp. 249-66.

Avramov, D., Chordia, T. and Goyal, A. (2006). 'The impact of trades on daily volatility', Review of Financial Studies, 19, pp. 1241-77.

Baillie, R. and DeGennaro, R. (1990). 'Stock returns and volatility', Journal of Financial and Quantitative Analysis, 25, pp. 203-14.

Barber, B. and Odean, T. (2011). 'The behavior of individual investors', in: Constantinides, G. M., Harris, M., Stulz, R. M. (Eds), Handbook of the Economics of Finance. North Holland, Amsterdam: Elsevier, pp. 1533-70.

Bauwens, L., Omrane, B. and Giot, P. (2005). 'News announcements, market activity and volatility in the euro/dollar foreign exchange market', Journal of International Money and Finance, 24, pp. 1108-25.

Beckers, S. (1983). 'Variance of security price returns based on high, low, and closing prices', Journal of Business, 56, pp. 97-112.

Bessembinder, H. and Seguin, P. (1992). 'Futures-trading activity and stock price volatility', Journal of Finance, 47, pp. 2015-34.

Therefore, information asymmetry rises and less informed investors face a higher adverse selection cost in trading with informed investors near the futures contract expiration. As a result, those uninformed traders who choose to trade with informed investors near the futures contract expiration will probably cause wider price movements so as to induce them to take the other side of the trade. 
Bessembinder, H. and Seguin, P. (1993). 'Price volatility, trading volume, and market depth: Evidence from futures markets', Journal of Financial and Quantitative Analysis, 28, pp. 21-39.

Bjønnes, G., Rime, D. and Solheim, H. (2007). 'The impact of different players on the volumevolatility relation in the foreign exchange market'. Working paper series, Norges Bank (Central Bank of Norway) Research.

Black, F. (1986). 'Noise', Journal of Finance, 41, pp. 529-43.

Blume, D., Easley, L. and O'Hara, M. (1994). 'Market statistics and technical analysis: The role of volume', Journal of Finance, 49, pp. 153-81.

Brockwell, P. and Davis, R. (1987). Time series: Theory and methods. Springer-Verlag.

Brown, S. (1990). 'Estimating volatility. Financial options: From theory to practice', (eds S. Figlewski, W. Silber and M. Subramanyam). Homewood, IL: Business One Irwin, pp. 516-37.

Brown, D. and Jennings, R. (1989). 'On technical analysis', Review of Financial Studies, 2, pp. 527-52.

Chen, Z. and Daigler, R. (2008). 'An examination of the complementary volume-volatility information theories', Journal of Futures Markets, 28, pp. 963-92.

Christensen, K. and Podolskij, M. (2007). 'Realized range based estimation of integrated Variance', Journal of Econometrics, 141, pp. 323-49.

Chou, R. Y. (2005). 'Forecasting financial volatilities with extreme values: The conditional autoregressive range (CARR) model', Journal of Money, Credit, and Banking, 37, pp. 561-82.

Clark, P. (1973). 'A subordinated stochastic process model with finite variance for speculative prices', Econometrica, 41, pp. 135-55.

Daigler, R. and Wiley, M. (1999). 'The impact of trader type on the futures volatility-volume relation', Journal of Finance, 6, pp. 2297-316.

Davidian, M. and Carroll, R. J. (1987). 'Variance function estimation', Journal of the American Statistical Association, 82, pp. 1079-91.

DeLong, B., Shleifer, A., Summers, L. and Waldman, R. (1990a). 'Noise trader risk in financial markets', Journal of Political Economy, 98, pp. 703-39.

DeLong, B., Shleifer, A., Summers, L. and Waldman, R. (1990b). 'Positive feedback in- vestment strategies and destabilizing rational speculation', Journal of Finance, 45, pp. 379-95.

Engle, R., Lilien, D. and Robins, R. (1987). 'Estimating time varying risk premia in the term structure: The ARCH-M model', Econometrica, 55, pp. 391-407.

Epps, T. and Epps, M. (1976). 'The stochastic dependence of security price changes and transaction volumes: Implications for the mixture of distributions hypothesis', Econometrica, 44, pp. 305-21.

French, K., Schwert, W. and Stambaugh, R. (1987). 'Expected stock returns and volatility', Journal of Financial Economics, 19, pp. 3-29.

Frommel, M., Mende, A. and Menkhoff, L. (2008). 'Order flows, news, and exchange rate volatility', Journal of International Money and Finance, 27, pp. 994-1012.

Gallant, A., Rossi, P. and Tauchen, G. (1992). 'Stock price and volume', Review of Financial Studies, 5, pp. 199-242.

Garman, M. and Klass, M. (1980). 'On the estimation of security price volatilities from historical data', Journal of Business, 1, pp. 67-78.

Glosten, L. and Milgrom, P. (1985). 'Bid, ask, and transaction prices in a specialist market with heterogeneously informed traders', Journal of Financial Economics, 13, pp. 71-100.

Grossman, S. and Stiglitz, J. (1980). 'On the impossibility of informationally efficient Markets', American Economic Review, 70, pp. 393-408.

Grundy, B. and McNichols, M. (1989). 'Trade and revelation of information through prices and direct disclosure', Review of Financial Studies, 2, pp. 495-526.

Harris, M. and Raviv, A. (1993). 'Differences of opinion make a horse race', Review of Financial Studies, 6, pp. 473-506. 
He, H. and Wang, J. (1994). 'Differential information and dynamic behavior of stock trading volume', Review of Financial Studies, 8, pp. 919-72.

Hindy, A. (1994). 'Dynamic price formation in a futures market with double auctions', Economic Theory, 4, pp. 539-64.

Holthaussen, R. W. and Verrecchia, R. (1990). 'The effect of informedness and consensus on price and volume behavior', Accounting Review, 65, pp. 191-208.

Hong, H. (2000). 'A model of returns and trading in futures markets', Journal of Finance, 55, pp. 959-88.

Ito, T., Lyons, R. and Melvin, M. (1988). 'Is there private information in the FX market? The Tokyo experiment', Journal of Finance, 53, pp. 1111-30.

Jones, C., Kaul, G. and Lipson, M. (1994). 'Information, trading and volatility', Journal of Financial Economics, 36, pp. 127-54.

Karpoff, J. (1987). 'The relation between price changes and volume: A survey', Journal of Financial and Quantitative Analysis, 22, pp. 109-26.

Kartsaklas, A. and Karanasos, M. (2009). 'Dual long-memory, structural breaks and the link between turnover and the range-based volatility', Journal of Empirical Finance, 16, pp. $838-51$.

Kawaller, I., Koch, P. and Peterson, J. (2001). 'Volume and volatility surrounding quarterly redesignation of the lead S\&P 500 futures contract', Journal of Future Markets, 12, pp. $1119-49$.

Keim, D. and Madhavan, A. (1995). 'Anatomy of the trading process: Empirical evidence on the behavior of institutional traders', Journal of Financial Economics, 37, pp. 371-98.

Kodres, L. and Pritsker, M. (1997). 'Directionally similar position taking and herding by large futures market participants', Risk Measurement and Systematic Risk, Proceedings, Board of Governors of the Federal Reserve, pp. 221-72.

Kyle, A. (1985). 'Continuous auctions and insider trading', Econometrica, 53, pp. 1315-35.

$\mathrm{Li}$, J. and Wu, C. (2006). 'Daily return volatility, bid-ask spreads, and information fow: analyzing the information content of volume', Journal of Business, 79, pp. 2697-740.

Martens, M. and van Dijk, D. (2007). 'Measuring volatility with the realized range', Journal of Econometrics, 138, pp. 181-207.

Milonas, N. (1986). 'Liquidity and price variability in futures markets', Financial Review, 21, pp. 211-37.

Murphy, K. and Topel, R. (1985). 'Estimation and inference in two-step econometric models', Journal of Business and Economics Statistics, 3, pp. 370-9.

O'Hara, M. (1995). Market microstructure theory. Blackwell Publishing.

Pagan, A. (1984). 'Econometric issues in the analysis of regressions with generated regressors', International Economic Review, 25, pp. 221-47.

Pagan, A. and Ullah, A. (1988). 'The econometric analysis of models with risk terms', Journal of Applied Econometrics, 3, pp. 87-105.

Parkinson, M. (1980). 'The extreme value method for estimating the variance of the rate of return', Journal of Business, 53, pp. 61-5.

Pffeiderer, P. (1984). 'The volume of trade and the variability of prices: A framework for analysis in noisy rational expectations equilibria', Working paper, Stanford University.

Phillips, G. and Weiner, R. (1994). 'Information and normal backwardation as deter- minants of trading performance: Evidence from the north sea oil forward market', The Economic Journal, 104, pp. 76-95.

Richard, S. and Sundaresan, M. (1981). 'A continuous time equilibrium model of forward prices and futures prices in a multigood economy', Journal of Financial Economics, 9, pp. 347-71.

Rogers, L. and Satchell, S. (1991). 'Estimating variance from high, low, and closing prices', Annals of Applied Probability, 1, pp. 504-12.

Ryu, D. (2015). 'The information content of trades. An analysis of the KOSPI200 index Derivatives', Journal of Futures Markets, 35, pp. 201-21. 
Samuelson, P. (1965). 'Proof that properly anticipated prices fluctuate randomly', Industrial Management Review, 6, pp. 41-50.

Schneider, J. (2009). 'A rational expectations equilibrium with informative trading volume', Journal of Finance, 64, pp. 2783-805.

Schwert, G. (1990). 'Stock volatility and the crash of '87', Review of Financial Studies, 3, pp. 77-102.

Seguin, P. (1991). 'The value of transactions reporting'. Working paper series, University of Michigan.

Shalen, C. (1993). 'Volume, volatility, and the dispersion of beliefs', Review of Financial Studies, 6, pp. 405-34.

Shu, J. and Zhang, J. E. (2006). 'Testing range estimators of historical volatility', Journal of Futures Markets, 26, pp. 297-313.

Tauchen, G. and Pitts, M. (1983). 'The price variability-volume relationship on speculative markets', Econometrica, 51, pp. 485-505.

Wiley, M. and Daigler, R. (1998). 'Volume relationships among types of traders in the financial futures markets', Journal of Futures Markets, 18, pp. 91-114.

Wang, J. (1994). 'A model of competitive stock trading volume', Journal of Political Economy, 102 , pp. $127-68$.

Wang, C. (2002). 'The effect of net positions by type of trader on volatility in foreign currency futures markets', Journal of Future Markets, 5, pp. 427-50.

Wang, J. (2007). 'Foreign equity trading and emerging market volatility: Evidence from Indonesia and Thailand', Journal of Development Economics, 84, pp. 798-811.

Yang, D. and Zhang, Q. (2000). 'Drift-independent volatility estimation based on high, low, open, and close prices', Journal of Business, 73, pp. 477-91.

\section{SUPPORTING INFORMATION}

Additional Supporting Information may be found in the online version of this article at the publisher's website.

\section{Appendix}

